\title{
Article \\ Hydrogen Permeability of Epoxy Composites as Liners in Lined Rock Caverns-Experimental Study
}

\author{
Dawid Gajda * and Marcin Lutyński \\ Faculty of Mining, Safety Engineering and Industrial Automation, Silesian University of Technology, \\ Akademicka 2, 44-100 Gliwice, Poland; marcin.lutynski@polsl.pl \\ * Correspondence: dawid.gajda@polsl.pl; Tel.: +48-880-205-614
}

Featured Application: Materials investigated in this paper can serve as a substitute of stainlesssteel liners in underground gas/hydrogen storage.

\begin{abstract}
Energy production from renewable energy sources is not stable and any fluctuations in energy productions need to be eliminated with underground energy storage. Demand of underground gas storage will be increasing, due to the switching to green energy, while the availability of underground storage sites, especially salt caverns suitable for hydrogen storage, is limited. The purpose of this paper is to compare the hydrogen permeability of different materials and select a proper liner material for hydrogen storage in Liner Rock Caverns or post mine workings. A variety of materials, like concrete, polymer concrete, epoxy resin, salt rock, and mudstone, were tested for gas permeability/hydrogen diffusion, using the combined Steady-State Flow/Carrier Gas methods. Results are shown in different units, providing the opportunity to compare the results with literature data. The permeability value of investigated epoxy resin is comparable to the salt rock (after creep process), which makes the epoxy resin a promising sealing liner for hydrogen and potential substitution of stainless-steel in Lined Rock Cavern (LRC) gas storage.
\end{abstract}

check for updates

Citation: Gajda, D.; Lutyński, M Hydrogen Permeability of Epoxy Composites as Liners in Lined Rock Caverns-Experimental Study. Appl. Sci. 2021, 11, 3885. https://doi.org/ 10.3390/app11093885

Received: 31 March 2021

Accepted: 23 April 2021

Published: 25 April 2021

Publisher's Note: MDPI stays neutral with regard to jurisdictional claims in published maps and institutional affiliations.

Copyright: (c) 2021 by the authors. Licensee MDPI, Basel, Switzerland. This article is an open access article distributed under the terms and conditions of the Creative Commons Attribution (CC BY) license (https:// creativecommons.org/licenses/by/ $4.0 /)$.
Keywords: hydrogen storage; sealing liners; Liner Rock Caverns; epoxy resin; hydrogen permeability

\section{Introduction}

Large scale energy storage is essential to increase the share of renewable energy in energy production. Power-to- $X$, and among them Power-to-gas technologies, could solve some of the problems related to the fluctuations in energy production from renewables, which is the main obstacle in their future implementation [1,2]. In Power-to-gas technologies, excess renewable energy is converted into hydrogen gas through PEM electrolysis or methane through methanation. This technology is already well developed and in connection with $\mathrm{CCU}$ technologies and can contribute to the reduction of $\mathrm{CO}_{2}$ emissions [3-5]. Hydrogen can be injected into natural gas grids and existing infrastructure can be used for such purposes [6,7]. Nevertheless, hydrogen storage is much more challenging than storing natural gas. High mobility and lightness, as well as reactivity in the presence of microorganisms cause nontrivial hydrodynamic effects and cause safety concerns $[6,8]$. Large scale hydrogen storage was already proven in salt caverns. A vast amount of research and modelling of salt cavern behavior was made, including the salt rock permeability, sealing properties, and general geomechanics of the cavern. Salt rock remains impermeable for gas in the zones, where the rock properties are not affected by the extraction process. Micro fracturing processes during the salt rock formation are also responsible for the presence of damage zones in salt rock, where the gas impermeability may be limited [9]. An alternative to store hydrogen in salt caverns is Lined Rock Caverns (LRC) technology which was successfully proven in natural gas storage. This technology uses underground hard rocks to store natural gas. The reservoir is fully isolated from the outer environment. Hard rock is only a mechanical base, where the cavern is drilled. Base rock does not need to have 
any isolating properties (like salt rock). Then, the shotcrete reinforcement, followed by the necessary installations, like drainage, are made. Final layer is the sealing lining. In order to ensure isolation and erosion, proven properties of sealing material are essential. A scheme of the LRC linings is shown in the Figure 1. In this technology, the most common lining material is steel $[10,11]$. It is justified to seek substitutional sealing materials beside stainless-steel, which will make the LRC storage more available and economical. One of the potential solutions is to use polymer-based concrete or epoxy resins, which are characterized by good sealing efficiencies. Research of gas permeability was done, including different methods, different polymer materials, and different gases. These studies include, inter alia, permeability of epoxy composites, using helium and $\mathrm{CO}_{2}[12,13]$, permeability of $\mathrm{N}_{2}, \mathrm{O}_{2}, \mathrm{CO}_{2}$, and $\mathrm{H}_{2} \mathrm{O}$ through number of polymer materials (inter alia LDPE, HDPE, PVC, polypropylene) [14], and hydrogen permeability of high density polyethylene (HDPE) [15]. However, research related with hydrogen permeability through epoxy resins are very limited [16,17].

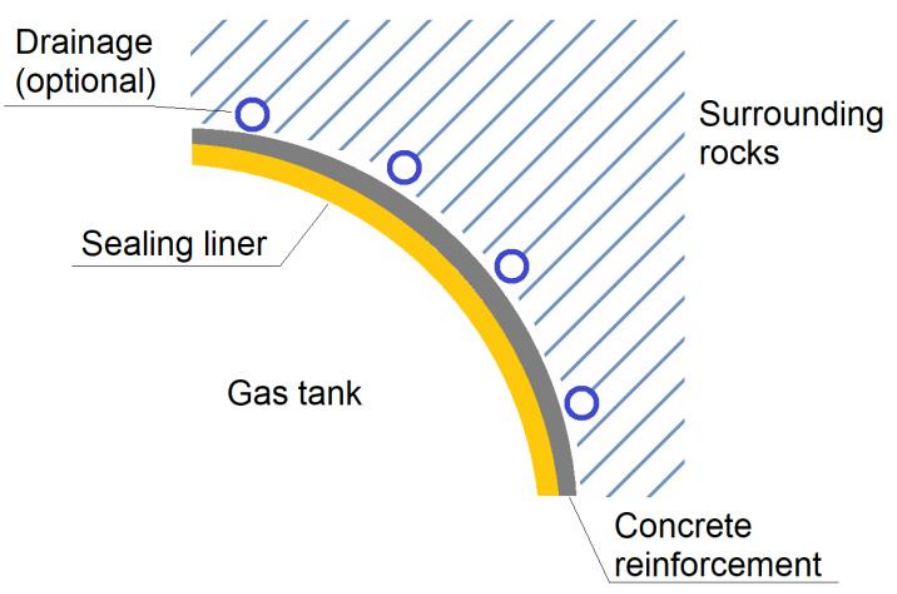

Figure 1. Scheme of the LRC linings.

The purpose of this work is to compare hydrogen permeability of different materials, which could be used as the sealing liner for hydrogen storage in LRC with focus on epoxy resins modified with various additives. Additionally, permeability of typical rocks that can be found around LRC, and rock salt, were also measured in order to compare results with available data. In this work, a setup combining Steady-State Flow Method and Carrier Gas Method was used for experiments. Samples were also examined under SEM to compare their structural properties.

\section{Experimental Methodology and Materials}

Setup used to investigate the hydrogen permeability was built in the Laboratory of Unconventional Gas and $\mathrm{CO}_{2}$ Storage at the Silesian University of Technology. Setup is combining the Steady-State Flow Method and Carrier Gas Method. Setup can be switched between mentioned methods, depending on the permeability coefficient of investigated samples. A scheme of the setup is shown in the Figure 2. It consists of the gas cylinder, pressure regulation valves, sample holder, precise gas pressure transducers, and gas concentration detector.

The upstream side is a reference gas. A blend of $10 \%$ of hydrogen in methane was used as a reference gas on the upstream side. Gas is applied on the sample, held in the PVC sleeve with confining pressure of water. Tests were conducted at 1.0 MPa feed gas pressure. During the test, the downstream side was filled with carrier gas (helium) at the pressure of $100 \mathrm{kPa}$. A single gas detector for hydrogen, with sensitivity of 2-2000 ppm, was plugged on the end of the setup for gas concentration measurements made periodically. After the measurement is done, the same socket is used to plug the carrier gas (helium), the downstream side is filled with after vacuuming. There is also a back pressure valve, 
which can be used to adjust the pressure on the downstream side, when there is a flow of gas through the sample. Back pressure valve is giving the possibility to set a steady pressure gradient through the sample, by adjusting the pressure on the upstream and downstream side.

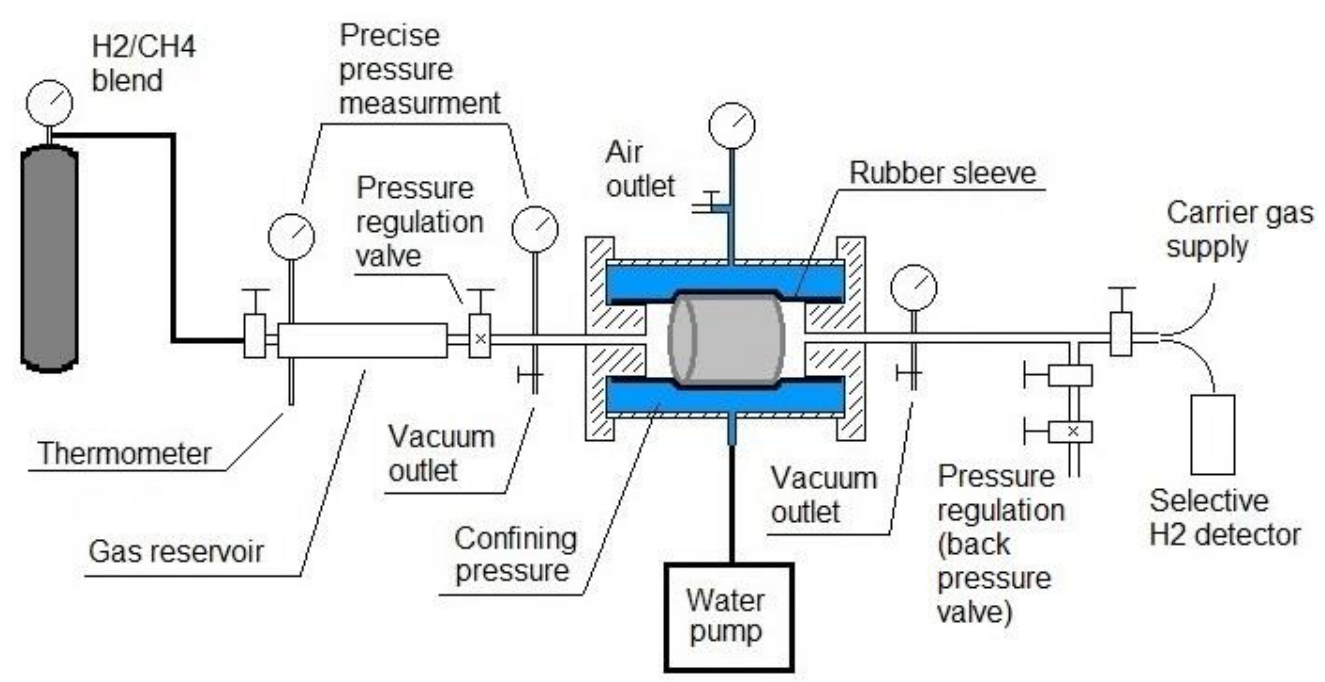

Figure 2. Steady-State Method/Carrier Gas Method setup.

Depending on the behavior of the sample, a proper method can be used. When a pressure increase on the downstream side is observed, there is a gas flow through the sample. It occurs, when the permeability of the sample is high enough to allow the gas to flow through the sample. Steady-State Flow Method is based on the pressure gradient in the sample, caused by the gas flow. Pressure gradient in the sample and gas pressure (together with temperature) in the reservoir are measured with precise pressure transducers (accuracy $0.5 \%$ FS). Filtration coefficient " $\mathrm{k}$ " can be calculated, using the Equations (1) and (2).

$$
q=\left(\frac{\left(\frac{p_{i} \cdot V_{r e s}}{Z_{i} \cdot R \cdot T}\right)-\left(\frac{p_{f} \cdot V_{\text {res }}}{Z_{f} \cdot R \cdot T}\right)}{t}\right) \cdot 22.4 \cdot 10^{-3}
$$

where:

$q=$ gas flow, $\mathrm{m}^{3} / \mathrm{s}$

$p_{i}, p_{f}=$ initial pressure $\left(p_{i}\right)$ and final pressure $\left(p_{f}\right)$ in reservoir, $\mathrm{Pa}$

$V_{\text {res }}=$ reservoir volume, $\mathrm{m}^{3}$

$Z_{i}, Z_{f}=$ gas compressibility factor at the initial $\left(Z_{i}\right)$ and final $\left(Z_{f}\right)$ pressure

$R=$ gas constant $\left(8.314463 \mathrm{~m}^{3} \cdot \mathrm{Pa} \cdot \mathrm{mol}^{-1} \cdot \mathrm{K}^{-1}\right)$

$T=$ gas temperature in reservoir, $\mathrm{K}$

$t=$ time, $\mathrm{s}$

$$
k=\frac{2 \cdot q \cdot p_{o} \cdot L \cdot \mu}{A \cdot\left(p_{i}^{2}-p_{o}^{2}\right)}
$$

where:

$k=$ permeability coefficient, $\mathrm{m}^{2}$

$q=$ gas flow, $\mathrm{m}^{3} / \mathrm{s}$

$p_{i}, p_{o}=$ average inlet $\left(p_{i}\right)$ and outlet $\left(p_{0}\right)$ gas pressure (pressure gradient), $\mathrm{Pa}$

$L=$ sample length, $\mathrm{m}$

$\mu=$ gas viscosity, Pa.s

$A=$ sample cross area, $\mathrm{m}^{2}$ 
When the gas permeability of the sample is low enough to prevent the gas flow through the sample, gas diffusion can be measured. In this case, Carrier Gas Method is used, which is based on the difference in gas concentration gradient through the sample. It is possible to measure it precisely with a single-gas hydrogen detector. Knowing the parameters of a reference gas on the upstream side, calculations of the permeability coefficient $\mathrm{P}$ are made, using a set of Equations (3)-(6). Using helium as a carrier gas, an ideal gas law can be assumed.

$$
V=\frac{R \cdot T}{p}
$$

where:

$V=$ molar volume in test conditions, $\mathrm{m}^{3} \cdot \mathrm{mol}^{-1}$

$R=$ gas constant: $8.314463 \mathrm{~J} \cdot \mathrm{mol}^{-1} \cdot \mathrm{K}^{-1}$

$T=$ gas temperature, $\mathrm{K}$

$p=$ gas pressure, $\mathrm{Pa}$

An amount of hydrogen diffused through the sample in a certain time can be calculated, using the Equation (4). In this case the volume of the downstream side of the setup needs to be determined. This was done by approximation of the inner volume of the pipes, based on the manufacturer's data and measurements of the setup. The volume of the downstream in the setup was $12.0 \mathrm{~cm}^{3}$

$$
N_{H_{2}}=\frac{c \cdot\left(\frac{N_{A}}{V}\right) \cdot v_{\text {downstream }}}{10^{6}}
$$

where:

$N_{H 2}=$ amount of hydrogen, diffused through the sample

$c=$ measured hydrogen concentration on downstream side, $\mathrm{ppm}$

$N_{A}=$ Avogadro's constant: 6.02214076.1023, $\mathrm{mol}^{-1}$

$V=$ molar volume, $\mathrm{m}^{3} \cdot \mathrm{mol}^{-1}$

$v_{\text {downstream }}=$ volume of downstream side of setup, $\mathrm{m}^{3}$

By knowing the molar volume of one mole of gas in Standard Temperature and Pressure conditions (STP: $0{ }^{\circ} \mathrm{C}, 100 \mathrm{kPa}$ ), the volume of gas in STP can be calculated, using Equation (5).

$$
V_{H_{2}}=\frac{N_{H_{2}} \cdot 22.414}{N_{A}}
$$

where:

$V_{H 2}=$ volume of hydrogen diffused through the sample, $\mathrm{cm}^{3} \mathrm{STP}$

$N_{A}=$ Avogadro's constant: 6.02214076.1023, $\mathrm{mol}^{-1}$

$22.414=$ mole volume of ideal gas in STP, $\mathrm{cm}^{3}$

Using the calculation above, gas permeability coefficient can be calculated with Equation (6).

$$
P_{H_{2}}=\frac{V_{H_{2}} \cdot l}{A \cdot t \cdot p}
$$

where:

$P_{H 2}=$ hydrogen permeability coeficcient, barrer

$V_{H 2}=$ volume of hydrogen diffused through the sample, $\mathrm{cm}^{3} \mathrm{STP}$

$l=$ sample length, $\mathrm{cm}$

$A=$ sample cross section area, $\mathrm{cm}^{2}$

$t=$ time, $\mathrm{s}$

$p=$ gas pressure (feed gas), $\mathrm{cmHg}(1 \mathrm{bar}=75 \mathrm{cmHg})$

Permeability coefficient of hydrogen is given in Barrer unit [18], presented in Equation (7).

Barrer unit is commonly used for presenting the permeability of membranes. However, it does not refer to the SI system, because of the pressure given in cmHg. Transforming the 
pressure into the SI unit (for example bar or Pa) is possible, however the results will not be comparable with the common literature data.

$$
\text { 1barrer }=\frac{\mathrm{cm}_{\mathrm{STP}}^{3} \cdot \mathrm{cm}}{\mathrm{cm}^{2} \cdot \mathrm{s} \cdot \mathrm{cmHg}} 10^{-10}
$$

Hydrogen diffusion is calculated as a diffusion coefficient $\mathrm{D}$, given in $\mathrm{m}^{2} / \mathrm{s}$, using the Fick's law [19] and following set of Equations (8)-(12), as well as values received from the Equations (3) and (4). For a gas diffusion through the polymer materials, the transport mechanism described by Fick's Law is accepted [20].

$$
J=-D \frac{\partial \phi}{\partial x}
$$

where:

$J=$ flux, amount of hydrogen diffusing through the area in time, $\mathrm{mol} \cdot \mathrm{m}^{-2} \cdot \mathrm{s}^{-1}$

$D=$ diffusion coefficient, $\mathrm{m}^{2} \cdot \mathrm{s}^{-1}$

$\phi=$ hydrogen concentration, $\mathrm{mol} \cdot \mathrm{m}^{-3}$

$x=$ length of hydrogen path, $\mathrm{m}$

$$
D=-J \frac{x_{2}-x_{1}}{\phi_{\text {downstream }}-\phi_{\text {upstream }}}
$$

where:

$D=$ diffusion coefficient, $\mathrm{m}^{2} \cdot \mathrm{s}^{-1}$

$J=$ flux, amount of hydrogen diffused through the area in time, $\mathrm{mol} \cdot \mathrm{m}^{-2} \cdot \mathrm{s}^{-1}$

$\phi_{\text {upstream }}=$ concentration of hydrogen (upstream), $\mathrm{mol} \cdot \mathrm{m}^{-3}$

$\phi_{\text {downstream }}=$ concentration of hydrogen $($ downstream $), \mathrm{mol} \cdot \mathrm{m}^{-3}$

$x_{2}-x_{1}=$ diffusion distance (sample length), $\mathrm{m}$

For a non-porous polymer material, the tortuosity is equal to 1 , thus the assumption can be made, that the hydrogen path is equal to sample length [21].

$$
J=-\frac{\left(\frac{N_{H 2}}{N_{A}}\right)}{A \cdot t}
$$

where:

$J=$ flux, amount of hydrogen diffused through the area in time, $\mathrm{mol} \cdot \mathrm{m}^{-2} \cdot \mathrm{s}^{-1}$

$N_{H 2}=$ amount of hydrogen elements, diffused through the sample, from Equation (4)

$N_{A}=$ Avogadro's constant: $6.02214076 \times 10^{23}, \mathrm{~mol}^{-1}$

$A=$ sample cross area, $\mathrm{m}^{2}$

$t=$ time, $\mathrm{s}$

$$
\phi_{\text {upstream }}=\frac{c_{u p}}{V \cdot 100}
$$

where:

$\phi_{\text {upstream }}=$ concentration of hydrogen (upstream), $\mathrm{mol} \cdot \mathrm{m}^{-3}$

$c_{u p}=$ concentration of hydrogen in refenrence gas, $\%$

$V=$ molar volume of gas $\mathrm{mol} \cdot \mathrm{m}^{-3}$, from Equation (3)

$$
\phi_{\text {downstream }}=\frac{\left(\frac{N_{H 2}}{v_{\text {downstream }}}\right)}{N_{A}}
$$

where:

$\phi_{\text {downstream }}=$ concentration of hydrogen $($ downstream $), \mathrm{mol} \cdot \mathrm{m}^{-3}$

$N_{H 2}=$ amount of hydrogen elements, diffused through the sample, from Equation (4) 
$v_{\text {downstream }}=$ volume of downstream side of setup, $\mathrm{m}^{3}$

$N_{A}=$ Avogadro's constant: $6.02214076 \times 10^{23}, \mathrm{~mol}^{-1}$

Measurements of concentrations at the downstream side were done every 2-4 days and given in the diffusion ratio in time (ppm of $\mathrm{H}_{2} / 24 \mathrm{~h}$ ). Structure of the samples was investigated, using HRSEM SUPRA 35 (Carl Zeiss AG, Oberkochen, Germany) Scanning Electron Microscope, since the chemical composition of the samples was not the scope of this study; the Energy Dispersive Spectrometry was not used for this research.

For the purpose of the study, several materials that could be used as a liner in underground excavation were selected. Samples under investigation can be divided into three general groups: epoxy resins with different additives; concrete; polymer-concrete and rocks (mudstone and rock salt). Materials were selected based on their common availability, low cost, and ease of preparation. Resin samples were prepared by mixing resin and cured for at least 7 days. During the pot time, samples were held in the oven in a temperature of $30{ }^{\circ} \mathrm{C}$ to accelerate the venting of the samples. Relative low temperature was set to simulate the thermal conditions in the excavations. Higher temperatures would be more efficient in the samples venting but would not be related with the actual underground temperature conditions, where the resins might be applied. Concrete and polymer-concrete samples were prepared by companies, according to their recipes and general standards for curing the concretes. Concrete samples were cored using a diamond core drill of $2.54 \mathrm{~mm}$ (1 inch) diameter. In Table 1 detailed description of samples is given.

Table 1. Details of investigated samples.

\begin{tabular}{|c|c|c|c|}
\hline Sample & Base & Physical Properties & Additives \\
\hline Concrete " 2 " & CEM II * & $\begin{array}{l}\text { Uniaxial strength: } 16.0 \mathrm{MPa} \\
\text { Water/cement ratio: n.a. } \\
\text { Casted } 3 \text { years prior } \\
\text { to experiment }\end{array}$ & Furnace slag (silica fumes) <35\% \\
\hline Concrete "1" & CEM I * & $\begin{array}{l}\text { Uniaxial strength: } 17.0 \mathrm{MPa} \\
\text { Water/cement ratio: } 0.47 \\
\text { Casted } 6 \text { months prior } \\
\text { to experiment }\end{array}$ & Limestone 7\% \\
\hline $\begin{array}{l}\text { Commercial } \\
\text { polymer-concrete "14-3" }\end{array}$ & $\begin{array}{c}\text { Classified due to company's } \\
\text { policy }\end{array}$ & $\begin{array}{l}\text { Casted } 3 \text { month prior } \\
\text { to experiment }\end{array}$ & Classified due to company's policy \\
\hline $\begin{array}{l}\text { Commercial } \\
\text { polymer-concrete "G1" }\end{array}$ & $\begin{array}{l}\text { Classified due to company's } \\
\text { policy }\end{array}$ & $\begin{array}{l}\text { Casted } 3 \text { month prior } \\
\text { to experiment }\end{array}$ & Classified due to company's policy \\
\hline Geopolymer & $\begin{array}{l}\text { Classified due to company's } \\
\text { policy }\end{array}$ & $\begin{array}{c}\text { Uniaxial strength: } 17.0-22.0 \mathrm{MPa} \\
\text { Casted } 3 \text { month prior } \\
\text { to experiment }\end{array}$ & Classified due to company's policy \\
\hline Mudstone (Carbon) & Clay minerals & - & - \\
\hline $\begin{array}{l}\text { Salt rock (Permian) } \\
\text { (before creep) }\end{array}$ & Sodium chloride & - & - \\
\hline $\begin{array}{l}\text { Salt rock (Permian) } \\
\text { (after creep) }\end{array}$ & Sodium chloride & - & - \\
\hline Epoxy resin & \multirow{5}{*}{$\begin{array}{l}\text { 2.2-Bis (4-hydroxyphenyl) } \\
\text { propane } \\
\text { with } \\
\text { epichlorohydrin } \\
\text { resin-hardener ratio: } 100: 12\end{array}$} & \multirow{5}{*}{$\begin{array}{c}\text { Viscosity: } 15,000-30,000 \mathrm{mPa} \cdot \mathrm{s} \\
\text { Epoxide number: } \\
0.48-0.52 \mathrm{~mol} / 100 \mathrm{~g} \\
\text { Chlorine content: }<0.6 \% \\
\text { Pot time: } 90 \mathrm{~min} .\end{array}$} & Mechanical impurities: $<0.03 \%$ \\
\hline $\begin{array}{l}\text { Epoxy resin } \\
\text { +graphite ( } \% \text { vol.) }\end{array}$ & & & Amorphous graphite $<50 \mu \mathrm{m}$ \\
\hline $\begin{array}{l}\text { Epoxy resin } \\
\text { +haloysite ( } 5 \% \text { vol.) }\end{array}$ & & & $\begin{array}{l}\text { Grinded halloysite } \\
<125 \mu \mathrm{m}\end{array}$ \\
\hline $\begin{array}{l}\text { Epoxy resin } \\
+ \text { fly ash ( } 5 \% \text { vol.) }\end{array}$ & & & $\begin{array}{l}\text { Sieved fly ash } \\
<125 \mu \mathrm{m}\end{array}$ \\
\hline $\begin{array}{l}\text { Epoxy resin } \\
\text { +fly ash ( } 30 \% \text { vol.) }\end{array}$ & & & $\begin{array}{l}\text { Sieved fly ash } \\
\quad<125 \mu \mathrm{m}\end{array}$ \\
\hline
\end{tabular}

* CEM I, CEM II-cement types according to Polish Standard: PN-EN 197-1:2012, PN-B-19707:2013. 


\section{Results}

Results of gas permeability of investigated samples are shown in Table 2. For the ease of comparison with other data, results are given in different units: permeability coefficient for hydrogen $\left(\mathrm{P}_{\mathrm{H} 2}\right)\left(\mathrm{cm}^{3} \mathrm{STP} \cdot \mathrm{cm} \cdot \mathrm{cm}^{-2} \cdot \mathrm{s}^{-1} \cdot \mathrm{cmHg}^{-1}\right.$ (Barrer)); diffusion coefficient $\left(\mathrm{m}^{2} \cdot \mathrm{s}^{-1}\right)$; and filtration coefficient ( $\mathrm{m}^{2}$ and $\mathrm{mD}$ (milidarcy)). Blend of hydrogen $(10 \%)$ in methane was used for the permeability tests. Results refer to this particular type of gas. For impermeable samples $\left(10^{-11} \mathrm{~cm}^{3} \mathrm{STP} \cdot \mathrm{cm} \cdot \mathrm{cm}^{-2} \cdot \mathrm{s}^{-1} \cdot \mathrm{cmHg}^{-1}\right.$ or lower), only hydrogen was permeating the sample, so these results refer to the pure hydrogen.

Table 2. Gas permeability of investigated samples.

\begin{tabular}{|c|c|c|c|c|}
\hline \multirow[b]{2}{*}{ Sample } & \multicolumn{2}{|c|}{ Permeability Coefficient $\mathbf{P}_{\mathrm{H} 2}$} & \multirow{2}{*}{$\begin{array}{c}\text { Diffusion Coefficient D } \\
\mathrm{m}^{2} / \mathrm{s}\end{array}$} & \multirow{2}{*}{$\begin{array}{c}\text { Filtration Coefficient } \mathbf{k} \\
\mathrm{m}^{2} \\
\mathrm{mD}\end{array}$} \\
\hline & $\begin{array}{c}\left(\mathrm{cm}^{3} \mathrm{STP} \cdot \mathrm{cm} \cdot \mathrm{cm}^{-2}\right. \\
\left.\mathrm{s}^{-1} \cdot \mathrm{cmHg}{ }^{-1}\right)\end{array}$ & Barrer & & \\
\hline Concrete " 2 " & $4.170 \times 10^{-4}$ & $4.170 \times 10^{6}$ & - & $\begin{array}{c}2.67 \times 10^{-16} \\
0.2703\end{array}$ \\
\hline Concrete " 1 " & $7.804 \times 10^{-5}$ & $7.804 \times 10^{5}$ & - & $\begin{array}{l}4.99 \times 10^{-17} \\
0.0505\end{array}$ \\
\hline $\begin{array}{l}\text { Polymer-concrete } \\
\text { "14-3" }\end{array}$ & $3.414 \times 10^{-5}$ & $3.414 \times 10^{5}$ & - & $\begin{array}{c}4.79 \times 10^{-17} \\
0.0485\end{array}$ \\
\hline Polymer-concrete "G1" & $6.214 \times 10^{-5}$ & $6.214 \times 10^{5}$ & - & $\begin{array}{c}7.48 \times 10^{-17} \\
0.0758\end{array}$ \\
\hline Geopolymer & $9.897 \times 10^{-5}$ & $9.897 \times 10^{5}$ & - & $\begin{array}{c}6.33 \times 10^{-17} \\
0.0641\end{array}$ \\
\hline Mudstone (Carbon) & $2.330 \times 10^{-7}$ & $2.330 \times 10^{3}$ & - & $\begin{array}{c}2.13 \times 10^{-19} \\
0.000216\end{array}$ \\
\hline $\begin{array}{l}\text { Salt rock (Permian) } \\
\text { (before creep) }\end{array}$ & $4.815 \times 10^{-7}$ & $4.815 \times 10^{3}$ & - & $\begin{array}{c}2.99 \times 10^{-19} \\
0.000303\end{array}$ \\
\hline $\begin{array}{l}\text { Salt rock (Permian) } \\
\text { (after creep) }\end{array}$ & $1.95 \times 10^{-11}$ & 0.195 & $1.586 \times 10^{-12}$ & $\begin{array}{c}5.80 \times 10^{-24} \\
1 \times 10^{-8}\end{array}$ \\
\hline Epoxy resin & $1.820 \times 10^{-11}$ & 0.182 & $1.479 \times 10^{-12}$ & $\begin{array}{c}6.12 \times 10^{-24} \\
1 \times 10^{-8}\end{array}$ \\
\hline $\begin{array}{l}\text { Epoxy resin } \\
+ \text { graphite ( } 5 \% \text { vol.) }\end{array}$ & $2.350 \times 10^{-11}$ & 0.235 & $1.907 \times 10^{-12}$ & $\begin{array}{c}7.13 \times 10^{-24} \\
1 \times 10^{-8}\end{array}$ \\
\hline $\begin{array}{l}\text { Epoxy resin } \\
\text { +haloysite ( } 5 \% \text { vol.) }\end{array}$ & $3.220 \times 10^{-11}$ & 0.322 & $2.637 \times 10^{-12}$ & $\begin{array}{c}9.78 \times 10^{-24} \\
1 \times 10^{-8}\end{array}$ \\
\hline $\begin{array}{l}\text { Epoxy resin } \\
+ \text { fly ash ( } 5 \% \text { vol.) }\end{array}$ & $1.770 \times 10^{-11}$ & 0.177 & $1.436 \times 10^{-12}$ & $\begin{array}{c}4.61 \times 10^{-24} \\
1 \times 10^{-8}\end{array}$ \\
\hline $\begin{array}{l}\text { Epoxy resin } \\
+ \text { fly ash ( } 30 \% \text { vol.) }\end{array}$ & $1.774 \times 10^{-11}$ & 0.177 & $1.411 \times 10^{-12}$ & $\begin{array}{c}5.24 \times 10^{-24} \\
1 \times 10^{-8}\end{array}$ \\
\hline
\end{tabular}

As expected, tests showed a wide range of measured permeability values. The highest gas permeability coefficient has multi-grain materials, like concrete, polymer-concrete, and geopolymer. Filtration coefficient " $\mathrm{k}$ " of investigated concrete samples is $10^{-17} \mathrm{~m}^{2}$ or higher. Lower gas permeability was observed for mudstone and salt rock before creep process. Both rocks have the filtration coefficient of $2.13 \times 10^{-19} \mathrm{~m}^{2}$ to $2.99 \times 10^{-19} \mathrm{~m}^{2}$, respectively. However, these rocks are still permeable for gases. In general, the lowest gas permeability has plain-structured materials, like epoxy resins and salt rock, after the creep process. Range of the filtration coefficient of these materials is of $10^{-24} \mathrm{~m}^{2}$. Salt rock samples became impermeable after about 12 days of exposure to $2.0 \mathrm{MPa}$ of confining pressure of water. Permeability dropped from $2.99 \times 10^{-19} \mathrm{~m}^{2}$ to $5.80 \times 10^{-24} \mathrm{~m}^{2}$. Hydrogen permeability of epoxy resin samples varied, depending on the additives in the resin. Admixture of 
halloysite or graphite powder caused the increase of hydrogen permeability. An exception is the addition of fly ash. Admixture of $30 \%$ of volume gave a similar, but slightly lower permeability, comparing to the pure epoxy resin sample. Significant share of fly ash in sample composition did not cause the deterioration of sealing properties.

Results were calculated for the steady-state diffusion. Usually, it took up to 3 weeks to achieve the steady-state diffusion. Increases in measured concentration of hydrogen per day of an example sample is presented in Figure 3. Because of the significant time required to complete the test for each sample, the hydrogen diffusion test was performed for a single gas pressure, which was 1.0 MPa. To verify the proper workings of the setup and sensitivity of the method, one test was extended and the feed gas pressure, after achieving steady-state diffusion, was increased. Pressure was increased after 24 days, from the value of 1.0 $\mathrm{MPa}$ to $1.7 \mathrm{MPa}$. After the pressure increase, several days were required to achieve the steady-state diffusion for a higher pressure. After that time, the measured concentration became stable again on a higher level. According to the Equations (3) and (4), increases of the pressure and permeability coefficient are linear. Pressure was raised by $70 \%$, which gave the increase of measured concentrations by more than $60 \%$ as well (after achieving steady-state diffusion). This confirmed that the measuring methodology was correct. Slightly lower increase in concentration, in comparison with the pressure increase, may be explained by higher confining pressure (double the gas pressure, which was approx. 3.6 MPa). It can cause a compaction of the sample, which caused a slight decrease of the permeability. This phenomenon was described for concrete samples in [19], as well as for the polymer materials, where hydrostatic compression effect occurs [15]. However, the scale of permeability decreased, as well as mechanism responsible for it, is different.

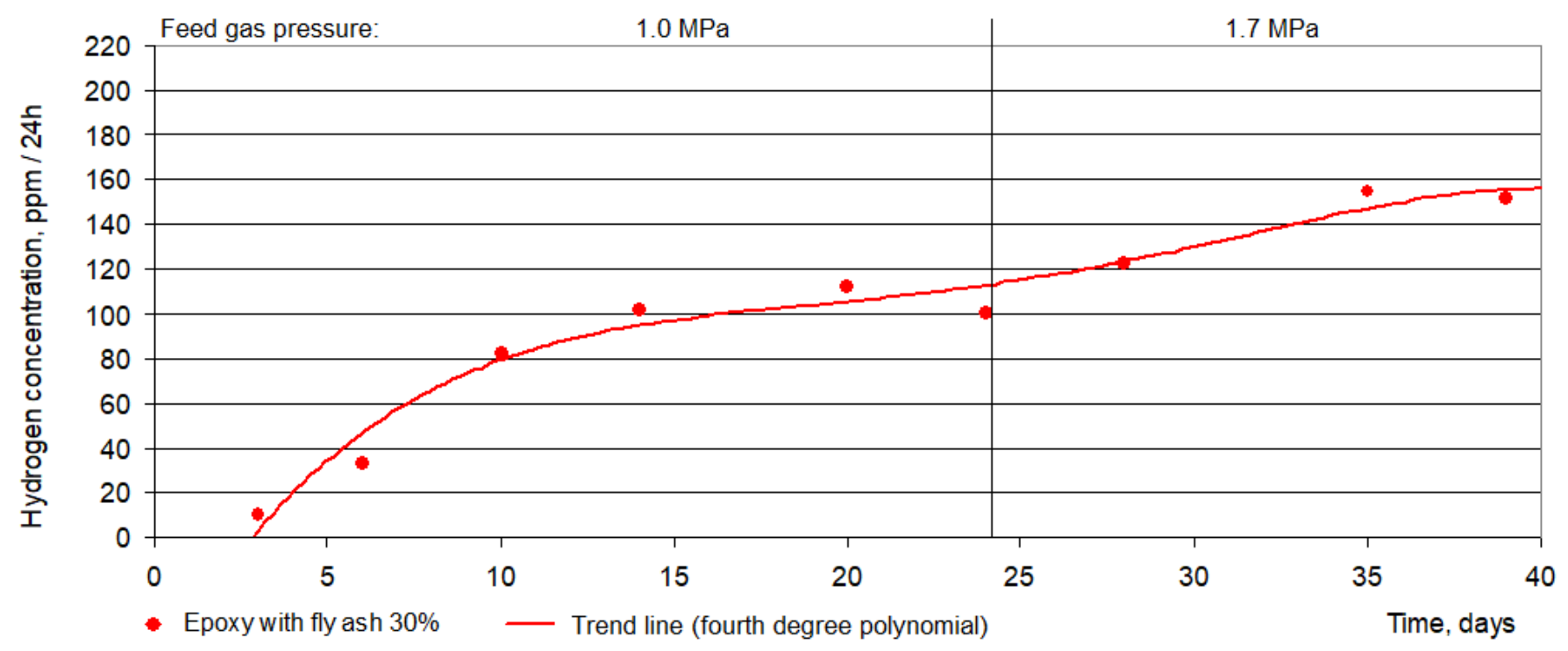

Figure 3. Increase of hydrogen concentration during the Carrier Gas Method test of epoxy resin with fly ash (30\% vol.) with 1.0 MPa and 1.7 MPa feed gas pressure.

To compare the gas permeability results of different materials with the microstructure of the samples, SEM imaging of selected samples was done. Structures of the samples are shown in Figure 4. An evident difference is seen in microporous and plain materials. Dark areas representing pores are clearly visible in concrete and mudstone samples under similar magnification (Figure $4 a, b$ ). In the plain samples, voids appear mostly on the contact surface with grains of additives (Figure 4e). 


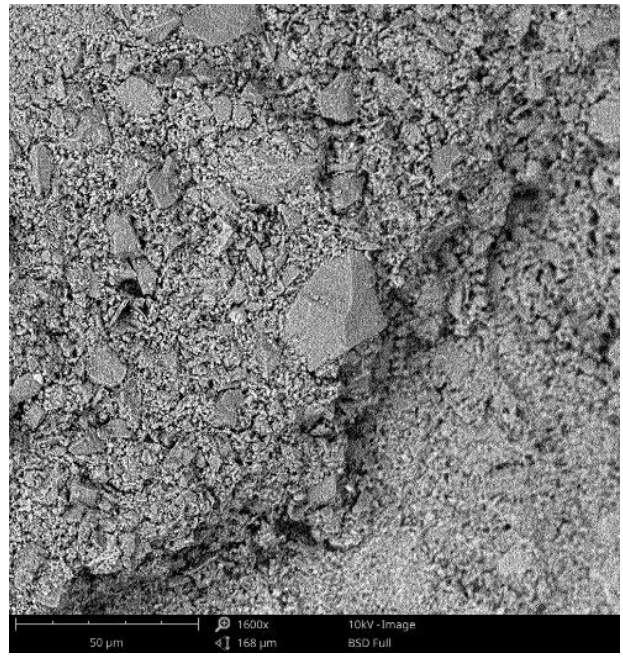

(a)

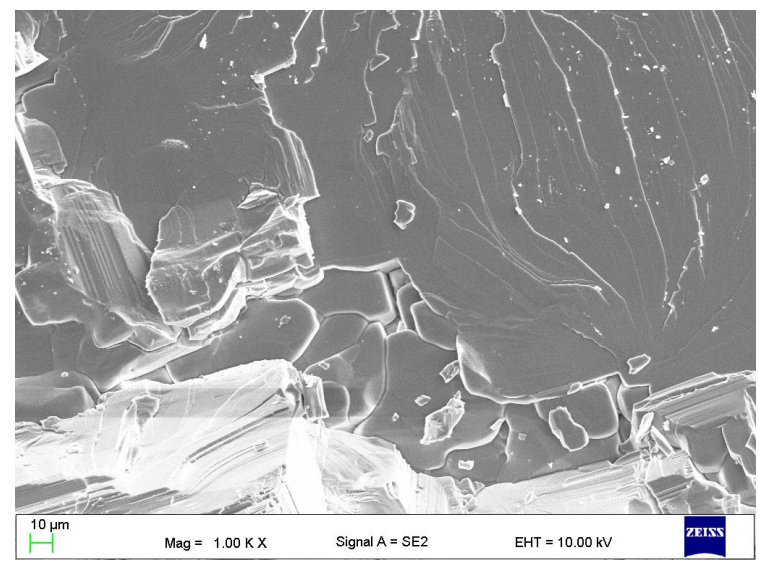

(c)

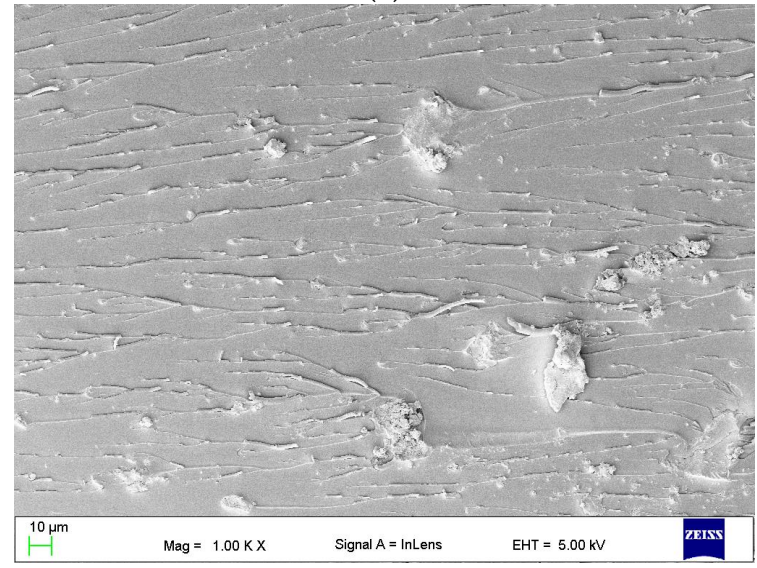

(e)

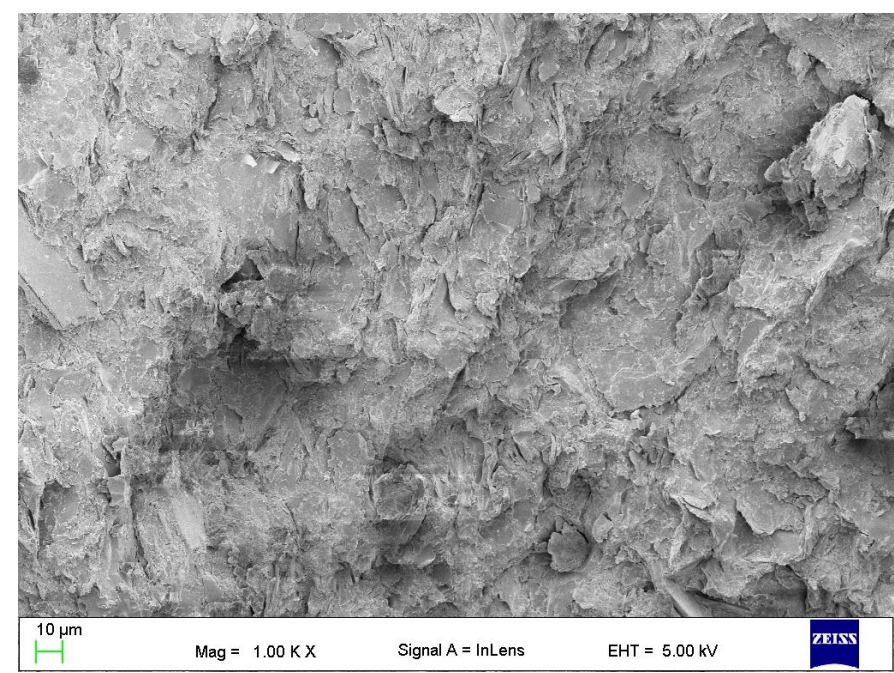

(b)

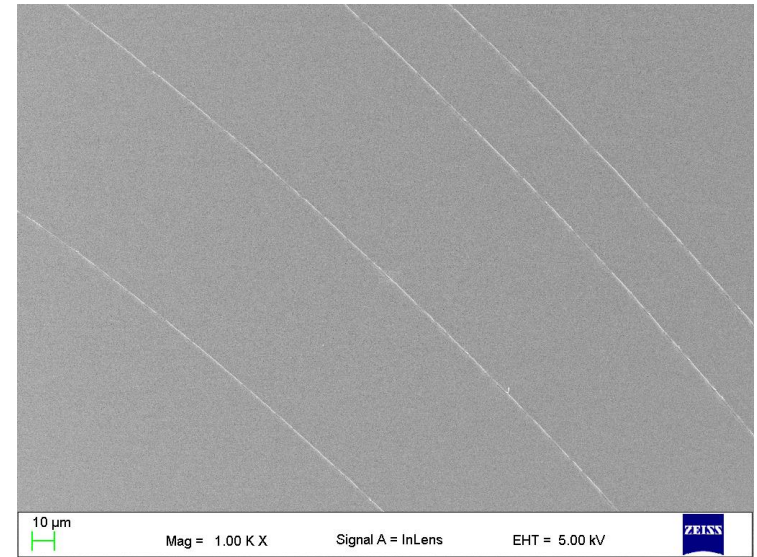

(d)

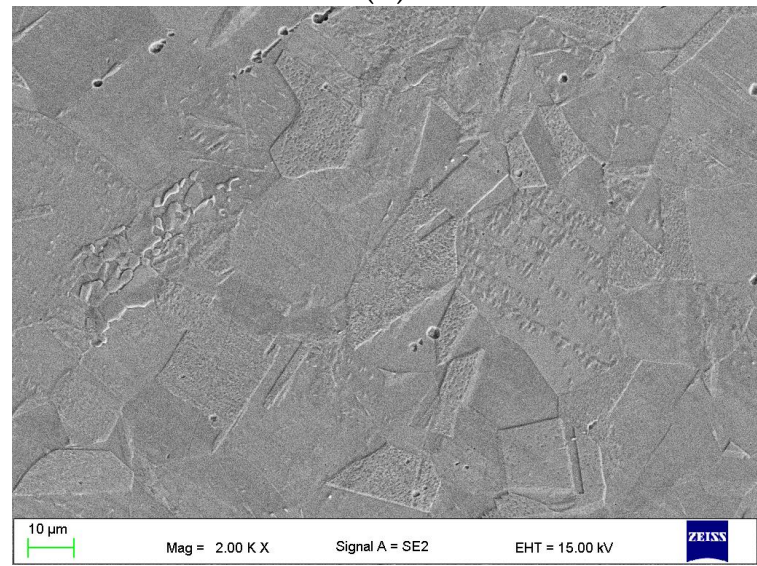

$(\mathbf{f})$

Figure 4. SEM imaging of the surface structure of investigated samples: (a) concrete "2" (year 2016); (b) mudstone (Carbon); (c) salt rock (Permian); (d) epoxy resin; (e) epoxy resin + graphite (5\% vol.); (f) stainless-steel.

\section{Discussion}

Differences of the gas permeability of investigated materials is caused by the differences in structure of tested materials, which lead to the different mechanisms of gas migration. Multi-grain materials, such as concrete or mudstone, have many pores and voids within the structure. Fine grains can decrease the gas permeability because the intergranular porosity is lower while the compaction of the material is higher; this phenomenon 
was also observed in other research [22]. However, gas flow through the sample is still noticeable and is the main mechanism of gas migration in that kind of material. However, it is not essential data for the purpose of this paper. Because of the low gas sealing properties of the investigated concretes, this type of material is not suitable for sealing purposes of underground excavations. However, it can still be a reinforcement and base liner.

Plain materials, like salt rock, epoxy, or steel, do not have pores and voids in their structure. Gas is not flowing through the sample (there is no pressure gradient along the sample). Hydrogen particles can diffuse through the material by dislocations in crystal structure. It is a linear defect that induces the tensile stress. Gas elements can diffuse much easier through those kinds of zones [23]. Lattice diffusion is also possible, but in much higher temperatures, transcending Tamman temperature (in this temperature atoms in solid material acquire enough energy to make bulk reactivity and mobility significant, usually approximately half of the melting temperature) [24]. In this case, research temperature was much below the Tamman temperature.

Interesting results were obtained with the fly ash epoxy sample. Graphite and halloysite are slightly increasing hydrogen permeability of the samples, while fly ash do not affect the sealing properties. Fly ash used for this research was not grinded but only sieved. Since fly ash from power plants is easily available, it could be a cost-effective filler by reducing the amount of epoxy resin in the sealing liner.

Obtained results of epoxy resin hydrogen permeability is slightly lower than presented in literature. Other research, presented collectively in [16], showed the hydrogen permeability of epoxy resin of approximately 1.0 Barrer, while performed research of investigated samples gave the permeability coefficient of approximately 0.2 Barrer. Results of hydrogen diffusion coefficient presented in [17], which was $6.9 \times 10^{-11} \mathrm{~m}^{2} / \mathrm{s}$, was also higher than the obtained $1.5 \times 10^{-12}$ from this research. Lower results may be caused by numerous factors, influencing on the gas permeability in polymeric materials like polymer chemistry (epoxide number), free volumes (crystallinity, orientation of molecules), porosity or voids (air inclusions), and fillers presence [16].

Permeability coefficient of 316 SS steel was calculated using the Equations (3)-(6), based on the literature data [25]. Permeability of $316 \mathrm{~L}$ steel were taken from [26,27]. Because of the sensitivity and construction of the setup, investigation of the steel samples was not possible. Permeability of steel is orders of magnitude lower than materials the setup is meant for. To investigate the steel or alloys, much thinner samples need to be used. The Setup is not designed for that kind of samples, but only for a core-shape samples. Calculated hydrogen permeability $\mathrm{P}_{\mathrm{H} 2}$ of $316 \mathrm{SS}$ steel was $4.6 \times 10^{-17} \mathrm{~cm}^{3} \mathrm{STP} \cdot \mathrm{cm} \cdot \mathrm{cm}^{-2} \cdot \mathrm{s}^{-1} \cdot \mathrm{cmHg}^{-1}$ $\left(4.6 \times 10^{-7}\right.$ Barrer), and given [26,27], hydrogen diffusion coefficient D of 316L steel was in range from $10^{-13}$ to $10^{-15} \mathrm{~m}^{2} / \mathrm{s}$.

\section{Conclusions}

Hydrogen permeability of investigated epoxy resins are similar to the permeability of salt rock in certain pressure conditions (after the salt creep). However, storage of pressurized gas in salt caverns is causing that kind of constant pressure anyway, which will lead to drop of salt permeability in time. Obtained results of epoxies are very promising for the purpose of use as the sealing liners in Lined Rock Caverns (LRC) underground gas storage, particularly for the storage of hydrogen. Epoxy resin can be used as a substitution of stainless-steel, because of the satisfying mechanical properties and extraordinary adhesive properties, which will be reinforcing the general construction, and thanks to the low density, the construction will not be overloaded at the same time. Despite the orders of magnitude higher of hydrogen permeability of epoxies, the hydrogen loss through this material is still acceptable, compared to the steel. For example, using a $3 \mathrm{~cm}$ thick epoxy liner in storing the $20 / 80$ hydrogen/methane blend at 1.0 MPa, the loss of hydrogen in the period of 30 days is only approximately $0.003-0.005 \%$ [28]. It is fully acceptable, taking the other properties and economy of epoxies. Only applying the liquid epoxy on the surface of cavern may cause some technical problems. Despite the better sealing properties of stainless-steel, the 
hydrogen permeability coefficient of investigated epoxy resin is still satisfying. Epoxies are also less susceptible to hydrogen erosion, which is making them a suitable material for hydrogen storage and cost-effective substitution for steel.

Author Contributions: Conceptualization D.G. and M.L., methodology D.G., investigation D.G., data curation D.G., formal analysis D.G. and M.L., writing—original draft preparation D.G., writingreview and editing M.L., supervision M.L. All authors have read and agreed to the published version of the manuscript.

Funding: This research was funded by Own Scholarship Fund of the Silesian University of Technology in year 2019/2020, grant number: 19/FSW18/0003-03/2019.

Institutional Review Board Statement: Not applicable.

Informed Consent Statement: Not applicable.

Data Availability Statement: All analyzed data in this study has been included in the manuscript.

Conflicts of Interest: The authors declare no conflict of interest.

\section{References}

1. Paul, D.; Ela, E.; Kirby, B.; Milligan, M. The Role of Energy Storage with Renewable Electricity Generation; National Renewable Energy Laboratory: Golden, CO, USA, 2010.

2. Renewable Energy Progress Report; European Comission: Brussels, Belgium, 2019.

3. Matos, C.R.; Carneiro, J.F.; Silva, P.P. Overview of Large-Scale Underground Energy Storage Technologies for Integration of Renewable Energies and Criteria for Reservoir Identification. J. Energy Storage 2019, 21, 241-258. [CrossRef]

4. Apostolou, D.; Enevoldsen, P. The past, present and potential of hydrogen as a multifunctional storage application for wind power. Renew. Sustain. Energy Rev. 2019, 112, 917-929. [CrossRef]

5. Bailera, M.; Lisbona, P.; Romeo, L.M.; Espatolero, S. Power to Gas projects review: Lab, pilot and demo plants for storing renewable energy and $\mathrm{CO}_{2}$. Renew. Sustain. Energy Rev. 2017, 69, 292-312. [CrossRef]

6. Altfeld, K.; Pinchbeck, D. Admissible Hydrogen Concentrations in Natural Gas Systems. Gas Energy 2013, 3, 36-47.

7. Kuczyński, S.; Łaciak, M.; Olijnyk, A.; Szurlej, A.; Włodek, T. Thermodynamic and Technical Issues of Hydrogen and MethaneHydrogen Mixtures Pipeline Transmission. Energies 2019, 12, 569. [CrossRef]

8. Panfilov, M. Underground and pipeline hydrogen storage. In Compendium of Hydrogen Energy; Elsevier BV: Amsterdam, The Netherlands, 2016; pp. 91-115.

9. Gabrielli, P.; Poluzzi, A.; Kramer, G.J.; Spiers, C.; Mazzotti, M.; Gazzani, M. Seasonal energy storage for zero-emissions multienergy systems via underground hydrogen storage. Renew. Sustain. Energy Rev. 2020, 121, 109629. [CrossRef]

10. Tengborg, P.; Johansson, J.; Durup, J.G. Storage of highly compressed gases in underground Lined Rock Caverns—More than 10 years of experience. In Proceedings of the World Tunnel Congress 2014-Tunnels for a Better Life, Foz do Iguacu, Brazil, 9-15 May 2014.

11. Natural Gas-Extraction to End Use. Natural Gas-Extraction to End Use; IntechOpen: London, UK, 2012; pp. 159-180.

12. Van Rooyen, L.J.; Karger-Kocsis, J.; Kock, L.D. Improving the helium gas barrier properties of epoxy coatings through the incorporation of graphene nanoplatelets and the influence of preparation techniques. J. Appl. Polym. Sci. 2015, 132. [CrossRef]

13. Zhang, Q.; Wang, Y.C.; Bailey, C.G.; Istrate, O.M.; Li, Z.; Kinloch, I.A.; Budd, P.M. Quantification of gas permeability of epoxy resin composites with graphene nanoplatelets. Compos. Sci. Technol. 2019, 184, 107875. [CrossRef]

14. Zeman, S.; Kubík, L. Permeability of Polymeric Packaging Materials. Tech. Sci. 2007, 10, 33-34. [CrossRef]

15. Fujiwara, H.; Ono, H.; Onoue, K.; Nishimura, S. High-pressure gaseous hydrogen permeation test method -property of polymeric materials for high-pressure hydrogen devices (1)-. Int. J. Hydrogen Energy 2020, 45, 29082-29094. [CrossRef]

16. Maxwell, A.S.; Roberts, S.J. Review of Data on Gas Migration through Polymer Encapsulants: Report to NDA-Radioactive Waste Management Directorate; Serco Ltd.: Osfordshire, UK, 2008.

17. Prewitz, M.; Gaber, M.; Müller, R.; Marotztke, C.; Holtappels, K. Polymer coated glass capillaries and structures for high-pressure hydrogen storage: Permeability and hydrogen tightness. Int. J. Hydrogen Energy 2018, 43, 5637-5644. [CrossRef]

18. Hagg, M.B. Gas Permeation Unit (GPU). In Encyclopedia of Membranes; Drioli, E., Giomo, L., Eds.; Springer: Berlin/Heidelberg, Germany, 2015.

19. Fick, A. On liquid diffusion. J. Membr. Sci. 1995, 100, 33-38. [CrossRef]

20. Choudalakis, G.; Gotsis, A. Permeability of polymer/clay nanocomposites: A review. Eur. Polym. J. 2009, 45, 967-984. [CrossRef]

21. Webb, S.W. 2-Gas Transport Mechanisms. In Gas Transport in Porous Media; Ho Clifford, K., Webb Stephen, W., Eds.; Springer: Berlin/Heidelberg, Germany, 2006; ISBN 978-1-4020-3962-1.

22. Gajda, D.; Liu, S.; Lutyński, M. The concept of hydrogen-methane blends storage in underground mine excavations-gas permeability of concrete. In Proceedings of the XVI International Forum-Contest of Students and Young Researchers "Topical Issues of Rational Use of Natural Resources", St. Petersburg, Russia, 17-19 June 2020. paper accepted. 
23. Zajęcia Dydaktyczne (Didactics Materials). Available online: http:/ /home.agh.edu.pl/ \{\}grzesik/ (accessed on 10 March 2021).

24. Anandprakash, K.P. Effect of Tammann Temperature and Relative Humidity on Lead Chromate and Magnesium-Based Compositions. Def. Sci. J. 1998, 48, 303-308. [CrossRef]

25. Henager, C.H. Hydrogen Permeation Barrier Coatings. In Materials for the Hydrogen Economy; Jones, R.H., Thomas, G.J., Eds.; CRC Press: Boca Raton, FL, USA, 2007; pp. 181-190.

26. Duportal, M.; Oudriss, A.; Feaugas, X.; Savall, C. On the Estimation of the Diffusion Coefficient and Distribution of Hydrogen in Stainless Steel. SSRN Electron. J. 2020. [CrossRef]

27. Kim, Y.; Kim, Y.; Kim, D.; Kim, S.; Nam, W.; Choe, H. Effects of Hydrogen Diffusion on the Mechanical Properties of Austenite 316L Steel at Ambient Temperature. Mater. Trans. 2011, 52, 507-513. [CrossRef]

28. Gajda, D. Epoxy resin for sealing the underground hydrogen storage reservoirs. Presented at the 5th International Conference on Energy Harvesting, Storage and Transfer (EHST’21), Niagara Falls, ON, Canada, 21-23 May2021. paper accepted. 